\title{
INVESTIGATING IMPACTS OF LARGE DAMS ON AGRICULTURAL LANDS AND DETERMINING ALTERNATIVE ARABLE AREAS USING GIS AND AHP IN ARTVIN, TURKEY
}

\author{
1Halil AKINCI, ${ }^{2}$ Ayse Yavuz ÖZALP, ${ }^{3}$ Mehmet ÖZALP \\ 1,2Artvin Çoruh University, Engineering Faculty, Department of Geomatics Engineering, Artvin, TURKEY \\ ${ }^{3}$ Artvin Çoruh University, Faculty of Forestry, Department of Forest Engineering, Artvin, TURKEY \\ 1hakinci@artvin.edu.tr, 2ayavuzozalp@artvin.edu.tr,3mozalp@artvin.edu.tr
}

(Geliş/Received: 07.11.2016; Kabul/Accepted in Revised Form: 12.12.2016)

\begin{abstract}
Large dams are generally built for the purposes of providing drinking or irrigation water, flood control, and producing hydroelectric power, but their constructions also result in some negative outcomes such as decreasing in flora and fauna diversity, inundation of arable lands, forest areas, cultural sites and involuntary displacement of people. The city of Artvin has been facing almost all of those negative effects since five large dams have being constructed on the section of the Çoruh River flowing within the city boundary. Three of those large dams completed submerged 795.60 ha of fertile agricultural land under the reservoir waters. The objective of this study was to determine potential suitable agricultural areas in substitution for those inundated due to these five dams. For this, the Analytic Hierarchy Process (AHP) method was used in this study. In the application, parameters including great soil groups, land use capability class, land use capability sub-class, soil depth, erosion degree, slope, aspect, elevation and other soil properties were used. A suitability map was created and separated into 5 categories according to the land suitability classification provided by the FAO. After deducting the forests, pastures, and reservoir areas, newly classified suitability map showed that $2.08 \%$ (11603.25 ha) of the study area was highly suitable, while $3.43 \%$ (19132.84 ha) was moderately suitable and $4.30 \%$ (23989.99 ha) w as marginally suitable for agricultural production. It $\mathrm{w}$ as interpreted that high slope, insufficient soil depth for agricultural production, and high erosion degree of the study area were effective factors in these findings.
\end{abstract}

Key Words: GIS, AHP, Agriculture, Land use suitability analysis, Artvin

\section{Artvin İlinde Büyük Barajların Tarım Arazileri Üzerindeki Etkilerinin İncelenmesi ve CBS ve AHP Kullanılarak Alternatif Ekilebilir Alanların Belirlenmesi}

ÖZ: Büyük barajlar, genellikle içme veya sulama suyu sağlama, taşkın kontrolü ve hidroelektrik enerji üretimi amaçlı inşa edilirler. Fakat büyük barajların inşası, flora ve fauna çeşitliliğinin azalması, ekilebilir arazilerin, orman alanlarının, tarihi ve kültürel alanların su altında kalması ve insanların isteksiz olarak yer değiştirmesi gibi bazı olumsuz sonuçlara neden olmaktadır. Artvin ili, Çoruh nehrinin şehrin sinırları içinde akan bölümünde inşa edilen beş büyük baraj nedeniyle tüm bu olumsuz etkilerle karşı karşıya kalmıştır. Tamamlanan üç büyükbaraj, 795.60 ha verimli tarım arazisini rezervuar suları altında bırakmıştır. Bu çalı̧̧manın amacı, bu beş büyük baraj nedeniyle sular altında kalan tarım arazilerinin yerine potansiyel tarım alanlarını belirlemektir. Bunun için çalışmada, Analitik Hiyerarşi

Note: This paper has been presented at the Selcuk International Scientific Conference on Applied Sciences (ISCAS 2016) held in Antaly a (Turkey), September 27-30, 2016.

\section{DOI: 10.15317/Scitech.2017.72}


Proses (AHP) yöntemi kullanılmıştır. Uygulamada, büyük toprak grupları, arazi kullanım kabiliyeti sınıfı, arazi kullanım kabiliyeti alt sınıfı, toprak derinliği, erozyon derecesi, eğim, bakı, yükseklik ve diğer toprak özellikleri parametreleri kullanılmıştır. Oluşturulan uygunluk haritası, FAO tarafında n sağlanan arazi uygunluk sınıflamasına göre 5 kategoriye ayrılmıştır. Ormanlar, meralar ve rezervuar alanları çıkarıldıktan sonra yeniden sinıflandırılan uygunluk haritası, çalışma alanının \%2.08'inin (11.603,25 ha) yüksek derecede, \%3.43'ünün (19.132,84 ha) orta derecede ve \%4.30'unun (23.989,99 ha) tarımsal üretim için düşük derecede uygun olduğunu göstermiştir. Bu sonuçlara ulaşılmasında, çalışma alanındaki eğimin yüksek olmasının, toprak derinliğinin tarımsal üretim için yeterli olmamasının ve çalışma alanının yüksek erozyon derecesine sahip olmasının etkili olduğu değerlendirilmiştir.

Anahtar Kelimeler: CBS, AHP, Tarm, Arazi kullanım uygunluk analizi, Artvin.

\section{INTRODUCTION}

It is known fact that rapid population grow th and migration require new area s in order to meet vital requirements particularly in cities. This situation leads to severe pressure on natural resources and inappropriate use of natural resources such as forests, pastures, wetland, agricultural lands, etc. against their potentials. Likewise, large investment projects such as roads, bridges, airports and dams destroy particularly agricultural lands and leads to their misuse. Therefore, protecting the nature and the land on which we live, taking maximum advantage of their existing potential, developing and presenting them to the use of the next generations can be possible only by developing land use plans by examining the usage options not conflicting with each other (Akten et al., 2009).

The prerequisite of land usage plan is to evaluate the land suitability. The mentioned evaluation provides guidance to the optimal usage of lands by providing information about opportunities and limits of land usage (Mokarram and Aminzadeh, 2010) and involves the decision to use the existing resources according to the their evaluated potential (Bandyopadhy ay et al., 2009). For this, first of all the most suitable land use type is determined with the suitability analy ses considering the land features and the user requirements (Akbulak, 2010; Amiri and Shariff, 2012). The land use suitability analysis is the determination of the suitability and the suitability level of a land for a particular use (agriculture, forest, recreation, etc.), and an important step of this determination process is to define the crit eria affecting the suitability of the land (Al-Shalabi et al., 2006). The fact that there are many criteria considerably complicates the land use suitability analysis. This is because in order to support the long-lasting use, without damage, of a particular land, it is also required to consider the criteria such as natural features of that land as well as its socioeconomic and environmental costs and results (Duc, 2006; Bandyopadhyay et al., 2009).

In addition to these, it is observed that there is not a certain standard for the parameters required to be considered for the evaluation of the land suitability potential for agriculture, and that the researches generally use the parameters that they can reach during their studies. When the mentioned studies are examined, it is observed that the topographic and soil characteristics of lands are commonly used. For example; during the agricultural land suitability analysis, Perveen et al. (2007) used the parameters of soil texture, soil moisture, soil consistency, $\mathrm{pH}$, soil drainage, organic matter content and slope. During their evaluation of arable lands, while Zengin and Yilmaz (2008) considered the parameters of land use capability classification (LUCC), soil depth, restrictive soil characteristics, drainage, erosion, slope, aspect, water existence, rainfall, temperature, vegetation cover and access; Akbulak (2010) used the parameters of slope, erosion, soil depth, restrictive soil characteristics, elevation and distance to road. During the land suitability analysis they conducted in Tabriz, Iran for agricultural production, Feizizadeh and Blaschke (2012) used 8 factors (altitude, slope, aspect, soil fertility, soil pH, temperature, rainfall and groundwater) included in four main groups as topography, climate, soil characteristics and water resources. Finally, during their studies where they determined the arable areas in Yusufeli district 
of Artvin, Akinci et al. (2013) used the parameters of great soil group, land use capability class, land use capability sub-class, soil depth, slope, aspect, elevation, erosion degree and other soil properties.

In the light of this information, the evaluation of the suitability of a certain land part for agricultural production requires the consideration of many criteria. Due to the fact that the criteria affecting the land suitability do not have the same importance levels, various methods were used for the determination of their importance and sub-criteria scores (Parakach, 2003). For example; in their study aiming to determine the physical land suitability for rice production, Perveen et al. (2007) used the Analytical Hierarchy Process (AHP) method. In addition, in their study integrating GIS and AHP methods, Mustafa et al. (2011) evaluated the suitability of the agricultural lands for some crops to be grown during summer and winter in Kheragarh Tehsil area of India. Moreover, in a similar study for searching the optimal use of land resources for agricultural production, Feizizadeh and Blaschke (2012) conducted a land suitability analysis based on GIS and AHP method. Akinci et al. (2013) also used GIS and AHP methods in order to determine the alternative agricultural lands for Yusufeli (Artvin) district since the current agricultural lands to be inundated by the reservoir water of Yusufeli Dam. Therefore, when reviewing the current literature, it can be clearly seen that many researchers such as Mishra et al. (2015); Bozdağ et al. (2016); Romeijn et al. (2016); Yalew et al. (2016), and Pramanik (2016) used GIS and AHP methods in respect to both analyzing the suitability of agricultural land and producing related maps.

On the other hand, as is known; mostly constructed to provide potable and/or irrigation water, to prevent flood and to produce hydroelectric power, the large dams have negative influences such as forcing people to migration, destroy of cultural and historical heritage, submerging agricultural and forest lands and decrease of flora and fauna diversities. Artvin city was affected all of these negative influences due to the five large dams of which four were completed and one is under construction on Çoruh River. In the districts having the mentioned dams, the fertile agricultural lands and many villages were partially or totally submerged and this led the people to migrate to city centers or other cities.

For this reason, this study aimed to determine the lands suitable for agriculture to be alternatives for the agricultural lands submerged/to be submerged due to the dams in the region including Murgul, Borçka, Ardanuç, Yusufeli and Central districts having the five dams whose constructions were completed and who are under construction on Çoruh River. In order to realize this objective, AHP method integrated with GIS was applied since it is considered as one of the most commonly used multicriteria decision-making approaches in the literature for analyzing the suitability of agricultural lands. As a result of this study, the distribution and the sizes of the lands suitable for agriculture were determined in the mentioned districts.

\section{MATERIAL AND METHOD}

\section{Study Area}

The study was carried out in area covering the administrative borders of Murgul, Borçka, Central, Ardanuç and Yusufeli districts and the lower part of Çoruh River where a total of five large dams, of which three of them (Muratli, Borçka, Deriner) were completed and two of them (Artvin and Yusufeli) are still under construction. The research area is located between the northern latitudes of $40 \mathrm{o} 34^{\prime} 20^{\prime \prime}-$ $41031^{\prime} 30^{\prime \prime}$ and the eastern longitudes of $41^{\circ} 9^{\prime} 25^{\prime \prime}-42^{\circ} 22^{\prime} 46^{\prime \prime}$ and it covers a surface area of approximately 557819.20 ha (Figure 1 ).

Out of all the dams projected on Çoruh River, the reservoirs of the already completed Muratli, Borçka and Deriner Dams started to be filled with water in 2005, 2006 and 2012, respectively. These dams have inundated 795.60 ha agricultural area along with impacting 49 villages and 1 neighborhood totally and/or partially. On the other hand, Artvin and Yusufeli Dams are being constructed and the former one has started to collect $w$ ater in its reservoir in 2015. These two dams have left a total of 1164.40 ha arable land under inundated (Yıldırımer, 2013), making up about $9 \%$ of the whole surface area of the Artvin province. The arable lands in the province generally consist of small family-run establishments 
and thus, the agricultural production model is completely based on manpower with almost no mechanical operations. Plant production is mostly done in the arable lands found along the valley plains formed by Çoruh River and its tributaries while animal production is carried out in upper sections of the valley (Yavuz Özalp et al., 2013).

\section{Parameters Used in the Land Suitability Analyses}

For identifying parameters and the method in determining lands suitable for agriculture, the study done by Akınci et al (2013) in Artvin was followed. In this respect, in order to analyze the research area for lands suitable for agriculture, nine parameters including great soil group (GSG), land use capability class (LUCC), land use capability sub-class (LUCS), soil depth, slope, aspect, elevation, erosion level and other soil properties (OSP) were used.

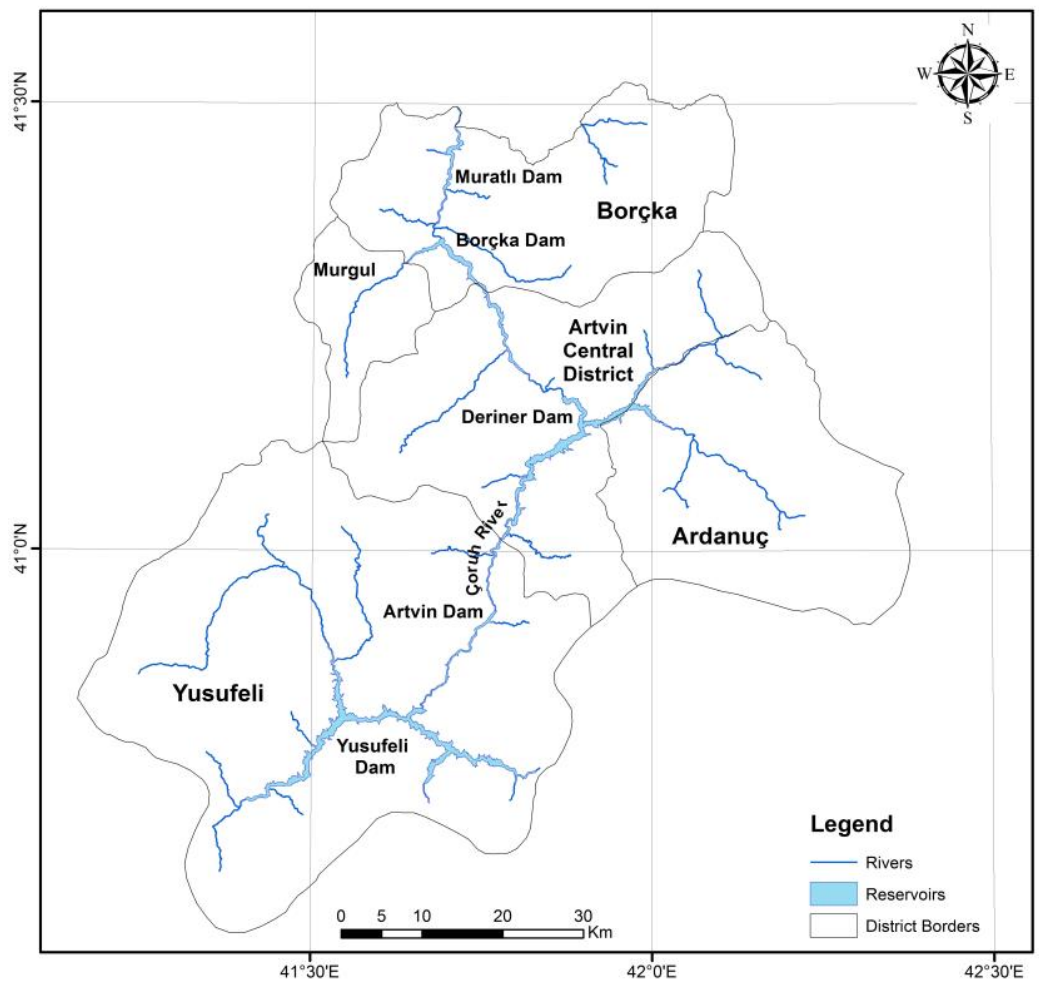

Figure 1. Study area map

Great Soil Group: Soil classification systems were created to help determining both the conditions for soil formation process and the behaviours of the soils providing contribution in estimating the soil performance for agricultural production. Thus, it is crucial to know the dominant soil class when deciding on the suitability of land for agricultural production (Akinc1 et al., 2013). In this respect, the dominant soil group in the study area is classified as brown forest soil with $50.57 \%$ (Table 1 ).

Land use capability class: Land use capability class (LUCC), in general, demonstrates the suitability of a given soil for the cultivated plants. In forming LUCCs, soils are grouped based on the constraints they bring to the agricultural products to be cultivated on them, the risk for loss of the crops in case the soils are used for cultivation and the reactions the soils will give to management applications (Akıncr et al., 2013). In the study area, the prevalent LUCC is class VII with $66.02 \%$ while the classes of I, II, III and IV known as suitable for agricultural production only consists of $3.62 \%$ (Table 1 ).

Land use capability sub-class: Land use capability sub-class (LUCS) represents the prevalent constraints determining the capability class (Akıncı et al., 2013). The problems of soil inadequacy, slope 
and erosion damage related to the steepness exist in $76.39 \%$ of the study area (Table 1 ). In addition, there are issues of inadequate drainage, wetness, and flood damage observed in the area.

Soil depth: Soil depth is the most important soil characteristic affecting the hydrologic properties of soils and its behaviors against erosion. Changes in soil depth is connected with processes of soil formation including chemical weathering of parent rock, loss of material formed through this weathering and transportation of soil by means of erosion (Fu et al., 2011). Besides the age pf soil formation, soil depth is also directly associated with topography, parent material, living organisms and climate (Gessler et al., 2000). The great degree of steepness in the study area caused soil depth to be low. As show $n$ in Table 1, approximately $75 \%$ of the study area is classified as shallow or very shallow while the percentage of deep and medium-deep soils regarded as more suitable for plant cultivation is determined to be $10.99 \%$ (Table 1) in respect to soil depth.

Erosion: Erosion is an important criteria reducing soil fertility by negatively affecting the physical, chemical and biological properties of soils. Erosion reduces the soil depth required for the development of plant roots and the amount of water needed by plants, decreases the cont ent of nutritional elements and organic matter and consequently leads to the formation of poor soil that is unsuitable for cultivation of plants (Lobo et al., 2005). With this respect, in about $64.01 \%$ and $21.92 \%$ of the study area suffers from severe and moderate erosion, respectively (Table 1 ).

Other soil properties: Among the other soil properties limiting plant production in the study area is the rockiness with $44.30 \%$. Moreover, there are problems of stoniness and inadequate drainage (Table 1). These mentioned problems are thought to be occurred as a result of erosion damage.

Elevation: Elevation is a crucial factor playing a part in variation of vegetation cover by affecting temperatures to change, particularly in highlands. As known, temperatures fall by about $0.5 \mathrm{Co}$ vertically for every $100 \mathrm{~m}$ within the first $4 \mathrm{~km}$ of the troposphere whereas it drops by 0.6 Co after $4 \mathrm{~km}$ and by $0.7-0.8$ Co near the tropopause. As a general rule, for each $100 \mathrm{~m}$ increase in elevation on mountains, it corresponds to $100 \mathrm{~m}$ of divergence from south to north or from lower latitudes to higher latitudes. In other words, when going up about $100 \mathrm{~m}$ on the mountains, the vegetation periods and blooming of plants expected to be delayed by 4 to 6 days (Atalay, 2006). This, in turn, negatively impacts the diversity of plants to be selected for agricultural production. It was found that the elevation ranges from $50 \mathrm{~m}$ to $3930 \mathrm{~m}$ in the study area and approximately $55 \%$ of the research area has elevation over $1500 \mathrm{~m}$.

Slope: Both the thickness of the soil layer (Atalay, 2006) and control of erosion are greatly affected by slope degree (Koulouri and Giourga, 2007) of an area. With the increase in degree of slope, the sediment amount transported with erosion rises while the thickness of soil lay ers drops. This, in turn, negatively affects soil properties, causing decrease in production and fertility of soils. The slope was over $30 \%$ for about $85 \%$ of the lands in the study area, indicating that the most of the research site lies within the classes of very steep and rugged (Table 1).

Aspect: In order to keep their physiological activities, plants require sun exposure at certain amounts and intervals. In this respect, it is a general fact that most cultivated plants show optimum grow th in the aspects of southern and western because these two receive sunlight for a considerable part of the day.

For this reason, the aspect should be considered as a criterion for determining suitable lands for agricultural production (Akıncı et al., 2013). When considering the study site for this parameter, it was determined that almost $62 \%$ of the area properly receives sunlight (Table 1 ).

\section{The Analytic Hierarchy Process (AHP)}

Developed as a model to solve problems of multi-criteria decision-making, the Analytic Hierarchy Process (AHP) was introduced by Thomas L. Saaty in 1997 (Kavas, 2009). The AHP method helps users to define the weights of the parameters for solving multi-criteria problems and thus it is one of the most widely known and used model. In the AHP method, for every problem, there is a hierarchical model 
having objectives, criteria, sub-criteria and alternatives are used (Saaty, 1990). When the problem is set on a hierarchical frame, the weights of the criteria forming the hierarchy are estimated (Öztürk and Batuk, 2010). In order to evaluate the criteria found in a level compared with other criteria included in the next hierarchy level, scoring is done by utilizing the preference scale according to Saaty (1980) and a pairwise comparison matrix is formed (Saaty, 1980; Saaty, 2004). The pairwise comparison matrix consists of $n^{*}(n-1) / 2$ comparisons for $n$ number of elements (Malczew ski, 1999; Öztürk and Batuk, 2010). 
Table 1. Areal and percentile distributions of the main and sub-criteria parameters in the study area

\begin{tabular}{|c|c|c|c|c|c|}
\hline Main criteria & Weight & Sub-criteria & Area (ha) & Area (\%) & Score \\
\hline \multirow{9}{*}{ GSG } & \multirow{9}{*}{0.278} & A (alluvial) & 1375.25 & 0.25 & 10 \\
\hline & & Y (high mountain meadow soils) & 69006.39 & 12.37 & 10 \\
\hline & & M (brown forest soils) & 282114.49 & 50.57 & 8 \\
\hline & & P (red-yellow podzolic soils) & 66068.47 & 11.84 & 7 \\
\hline & & K (colluvial soils) & 357.69 & 0,07 & 7 \\
\hline & & X (basaltic soils) & 3279.63 & 0.59 & 7 \\
\hline & & $\mathrm{N}$ (non-calcic brown forest soils) & 71900.93 & 12.89 & 5 \\
\hline & & CE (chestnut soils) & 853.08 & 0.15 & 3 \\
\hline & & Other (water bodies, urban fabric etc.) & 62863.27 & 11.27 & 0 \\
\hline \multirow{6}{*}{ LUCC } & \multirow{6}{*}{0.233} & I, II, III & 3452.25 & 0.62 & 10 \\
\hline & & IV & 16716.65 & 3.00 & 8 \\
\hline & & VI & 106483.32 & 19.09 & 2 \\
\hline & & VII & 368303.72 & 66.02 & 1 \\
\hline & & VIII & 57878.61 & 10.38 & 0 \\
\hline & & Other (water bodies, urban fabric etc.) & 4984.65 & 0.89 & 0 \\
\hline \multirow{6}{*}{ LUCS } & \multirow{6}{*}{0.162} & e (slope and erosion damage) & 53467.43 & 9.59 & 3 \\
\hline & & es (slope and erosion damage, soil inadequacy) & 359697.59 & 64.48 & 2 \\
\hline & & se (soil inadequacy, slope and erosion damage) & 12954.30 & 2.32 & 2 \\
\hline & & sw (soil inadequacy, wetness, inadequate drainage) & 67555.09 & 12.11 & 3 \\
\hline & & w (wetness, inadequate drainage or flood losses) & 1206.57 & 0.22 & 5 \\
\hline & & Other (water bodies, urban fabric etc.) & 62938.22 & 11.28 & 0 \\
\hline \multirow{6}{*}{ Soil depth $(\mathrm{cm})$} & \multirow{6}{*}{0.116} & $\operatorname{Deep}(>90)$ & 563.90 & 0.11 & 10 \\
\hline & & Medium-deep (90-50) & 60673.93 & 10,88 & 8 \\
\hline & & Shallow $(50-20)$ & 195356.60 & 35.02 & 6 \\
\hline & & Very shallow $(20-0)$ & 225050.78 & 40.34 & 2 \\
\hline & & Litosolic & 14075.76 & 2.52 & 1 \\
\hline & & Other (water bodies, urban fabric etc.) & 62098.23 & 11.13 & 0 \\
\hline \multirow{6}{*}{ Slope $(\%)$} & \multirow{6}{*}{0.096} & $0-2$ & 2053.98 & 0,37 & 10 \\
\hline & & $2-6$ & 3649.77 & 0,65 & 8 \\
\hline & & $6-12$ & 12133.17 & 2.18 & 6 \\
\hline & & $12-20$ & 25548.48 & 4,58 & 4 \\
\hline & & $20-30$ & 41782.50 & 7.49 & 3 \\
\hline & & $>30$ & 472651.30 & 84.73 & 1 \\
\hline \multirow{4}{*}{ Aspect } & \multirow{4}{*}{0.040} & Flat, S,SE, SW & 209179.00 & 37.51 & 8 \\
\hline & & $\mathrm{E}, \mathrm{W}$ & 135959.22 & 24.37 & 7 \\
\hline & & $\mathrm{NE}, \mathrm{NW}$ & 141149.61 & 25.30 & 5 \\
\hline & & $\mathrm{N}$ & 71531.37 & 12.82 & 2 \\
\hline \multirow{6}{*}{$\begin{array}{l}\text { Elevation } \\
(\mathrm{m})\end{array}$} & \multirow{6}{*}{0.032} & $50-250$ & 5109.84 & 0.92 & 10 \\
\hline & & $250-500$ & 18870.84 & 3.38 & 9 \\
\hline & & $500-1000$ & 91128.33 & 16.34 & 8 \\
\hline & & $1000-1500$ & 136853.99 & 24.53 & 7 \\
\hline & & $1500-2000$ & 136893.15 & 24.54 & 5 \\
\hline & & $>2000$ & 168963.05 & 30.29 & 2 \\
\hline \multirow{5}{*}{ Erosion degree } & \multirow{5}{*}{0.025} & 1 (very weak) & 1375.25 & 0.25 & 10 \\
\hline & & 2 (moderate) & 122290.80 & 21.92 & 8 \\
\hline & & 3 (severe) & 357055.44 & 64.01 & 6 \\
\hline & & 4 (very severe) & 14234.45 & 2.55 & 4 \\
\hline & & Other (water bodies, urban fabric etc.) & 62863.26 & 11.27 & 0 \\
\hline \multirow{4}{*}{ OSP } & \multirow{4}{*}{0.018} & $\mathrm{y}$ (inadequate drainage) & 1300.29 & 0.23 & 6 \\
\hline & & $\mathrm{t}$ (stony) & 69697.51 & 12.49 & 4 \\
\hline & & $\mathrm{r}($ rocky) & 247103.57 & 44.30 & 2 \\
\hline & & Other (water bodies, urban fabric etc.) & 239717.83 & 42.98 & 0 \\
\hline
\end{tabular}


Solving a problem with AHP is carried out using the weights or priorities of the criteria determined by normalizing the pairwise comparison matrix. For this normalization, a "normalized pairwise comparison matrix" is generated by dividing the column elements of the matrix by the sum of each column. The elements in the rows of the obtained matrix are summed and the total value is divided by the number of elements in the row. At this point, a vector of priority or weight is obtained (Tombus, 2005). Weights are within the range of $0-1$, and the sum of them is equal to 1 (Malczew ski, 1999; Öztürk and Batuk, 2010).

There can be some level of inconsistencies occurring during the performing pairwise comparisons of criteria with the AHP. Thus, the logical consistency of these pairwise comparisons have to be tested (Öztürk and Batuk, 2010). For this, the consistency ratio developed by Saaty (1980) can be used in order to estimate the consistency of pairwise comparison judgments and it is calculated for the pairwise comparison matrix. As suggested by Saaty (1980), the upper limit for this ratio is " 0.10 ", indicating that the judgments exhibit a sufficient degree of consistency if it is below 0.10 and the assessment can be continued. However, if it is over 0.10 , then the judgments are seen as inconsistent and the quality of the judgments should to be improved. The consistency rate may be reduced through reviewing the judgments one more time (Öztürk and Batuk, 2007).

\section{Data sets and methodology}

The data regarding the topographical parameters such as slope, aspect and elevation were gathered from digitally-formatted standard topographical maps (1/25.000 scale). Firstly, the Digital Elevation Model (DEM) of the research area was generated using ArcGIS 10.2 softw are and then the maps of slope, aspect and elevation were created after this DEM was converted into the ESRI GRID format with a 30x30 m cell size.

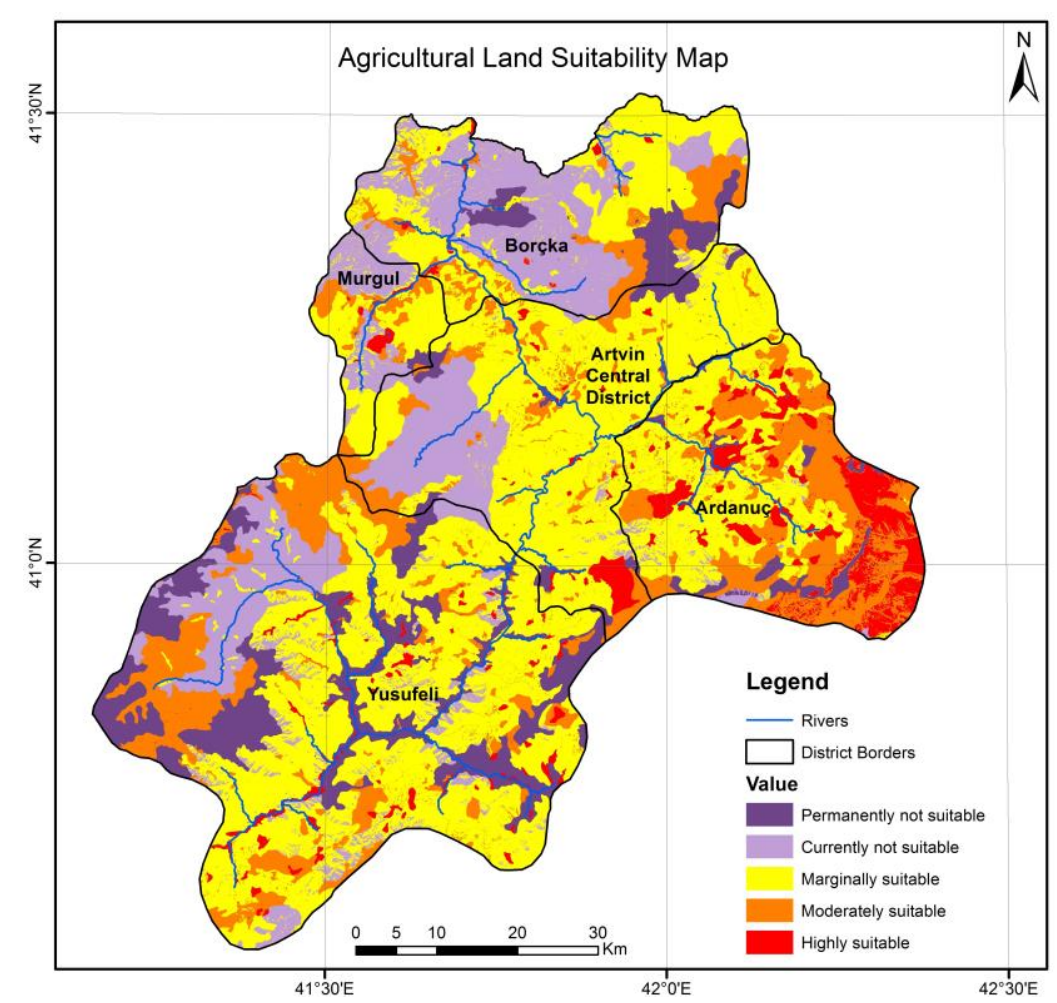

Figure 2. Agricultural land use suitability map

As for obtaining data in respect to soil properties, the $1 / 25.000$ scaled digital soil maps provided by the General Directorate of Agricultural Reform were used. Maps of soil properties such as GSG, LUCC, 
LUCS, soil depth, erosion degree and OSP for the study area (in 30x30 m cell size ESRI GRID format) were generated soil maps in ESRIShape format through considering the entity parameters found in the national soil database.

Current data of agricultural land, forest area and pasturelands in the study area were gathered from forest management plans created by the Artvin Regional Directorate of Forestry in the ESRI Shape format (in 1/25.000 scale). The areal coverage of the reservoirs was estimated using DEM after obtaining the coordinates and elevations of highest water-level for Yusufeli, Artvin and Deriner Dams thanks to the Artvin Regional Directorate of State Hydraulic Works.

In the next step, the weights of parameters and points of sub-parameters were obtained from the study by Akınci et al (2013) completed in Artvin's Yusufeli district. After the weights of parameters and the points of sub-parameters were assigned to the related layer, the raster maps of nine parameters were overlaid using both weighted sum and overlay analysis and land suitability maps of agricultural land use were created. Changing between 0.24 and 8.974, the suitability index for agricultural land use was classified into five classes according to the land suitability classification of FAO (1976) using classification method of natural breaks (Figure 2).

Finally, the suitability map for agricultural land use in the study area was generated by subtracting areas of forest, rangeland and dam reservoirs from the re-classified suitability map (Figure 3).

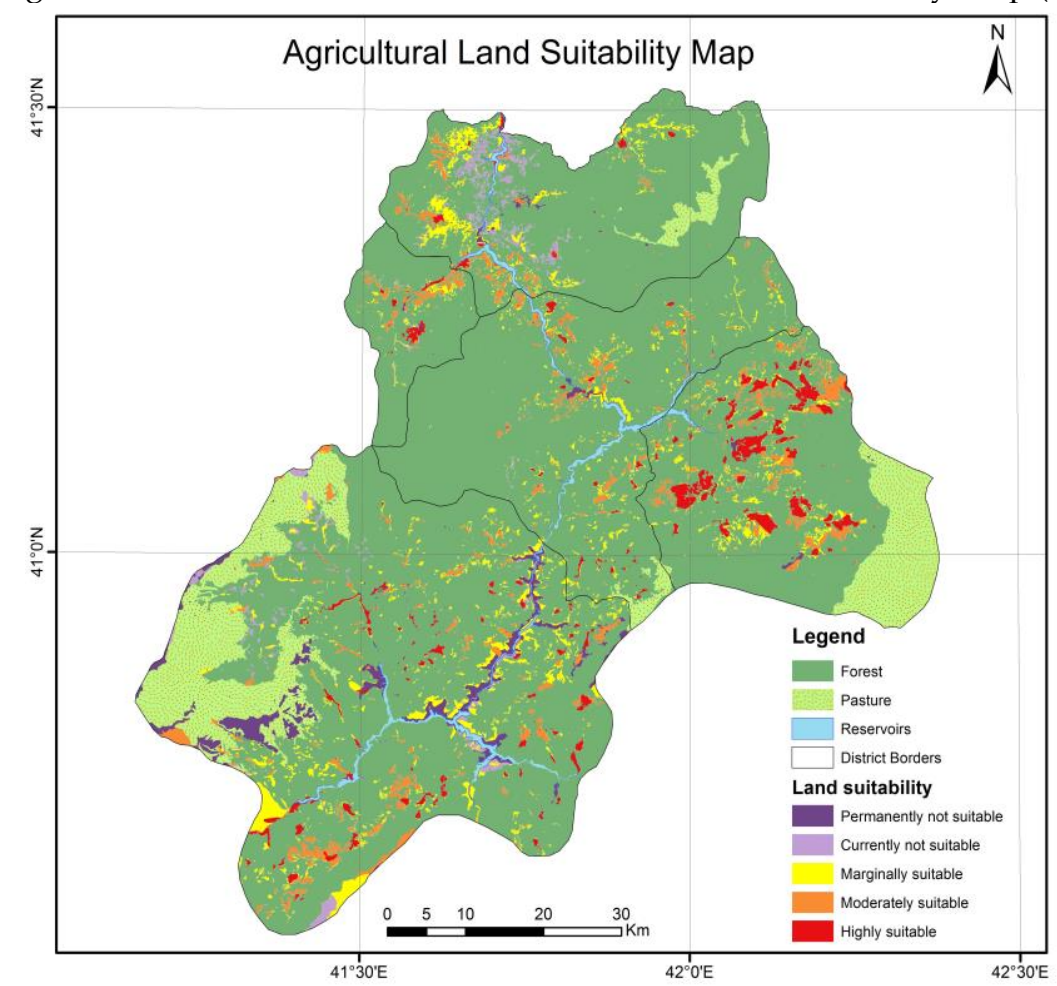

Figure 3. Suitability map obtained after removing pasture, forest lands and reservoirs

\section{RESULT AND DISCUSSION}

Considering the agricultural land use suitability map produced (Figure 3) and the data of Table 2, it $w$ as determined that the rate of the land permanently not suitable for agriculture $w$ as $11.41 \%(63659.62$ ha); that the rate of the land currently not being suitable for agriculture was $18.14 \%$ (101210.63 ha); that the rate of the land marginally suitable for agriculture was $47.85 \%$ (266890.49 ha); that the rate of the land moderately suitable for agriculture was $17.42 \%$ (97174.62 ha); and that the rate of the land highly suitable for agriculture was $5.18 \%$ (28883.53 ha) (Table 2).

$9.95 \%$ ( $55504.72 \mathrm{ha}$ ) of the study area is covered with pasture and $75.67 \%$ (422099.27 ha) of it is covered with land having forest (Table 2). $90.03 \%$ (240287.02 ha) of the lands that is marginally suitable 
for agricultural use, $79.8 \%$ (77548.88 ha) of the lands that is moderately suitable for agricultural us e and $54.91 \%$ (15861.18 ha) of the lands that is highly suitable for agricultural use coincide with forest and pasture lands.

These lands were excluded from the suitability map as agricultural activities cannot be conducted on forest and pasture lands in accordance with the statutory legislation in force in Turkey.

Table 2. The distribution of agricultural land suitability analysis results based on area and percentage

\begin{tabular}{|c|c|c|c|c|c|c|c|}
\hline \multirow[t]{2}{*}{ Suitability degree } & \multicolumn{2}{|c|}{$\begin{array}{l}\text { Total area classified } \\
\text { by the suitability } \\
\text { analysis }\end{array}$} & \multirow{2}{*}{$\begin{array}{l}\text { Areas to be } \\
\text { inundated by the } \\
\text { reservoirs } \\
\text { (ha) }\end{array}$} & \multirow{2}{*}{$\begin{array}{l}\begin{array}{l}\text { Area within } \\
\text { forestlands }\end{array} \\
\text { (ha) }\end{array}$} & \multirow{2}{*}{$\begin{array}{c}\text { Area within } \\
\text { pasturelands } \\
\text { (ha) }\end{array}$} & \multicolumn{2}{|l|}{$\begin{array}{l}\text { Suitable for } \\
\text { agricultural } \\
\text { production }\end{array}$} \\
\hline & (ha) & $(\%)$ & & & & (ha) & $(\%)$ \\
\hline $\begin{array}{l}\text { Permanently not } \\
\text { suitable }\end{array}$ & 63659,92 & 11,41 & 3406,55 & 33859,80 & 16504,05 & 9889,52 & 1,77 \\
\hline $\begin{array}{l}\text { Currently not } \\
\text { suitable }\end{array}$ & 101210,63 & 18,14 & 296,12 & 89450,71 & 4092,35 & 7371,45 & 1,32 \\
\hline Marginally suitable & 266890,49 & 47,85 & 2613,48 & 238485,26 & 1801,76 & 23989,99 & 4,30 \\
\hline Moderately suitable & 97174,62 & 17,42 & 492,90 & 52900,85 & 24648,03 & 19132,84 & 3,43 \\
\hline Highly suitable & 28883,53 & 5,18 & 1419,10 & 7402,65 & 8458,53 & 11603,25 & 2,08 \\
\hline Total & 557819,19 & 100 & 8228,15 & 422099,27 & 55504,72 & 71987,06 & 12,90 \\
\hline
\end{tabular}

The total size of the reservoir areas of the dams constructed on Çoruh River is 8228.15 ha. Considering the reservoir areas, it was calculated that a total part of 1912 ha of the lands being suitable for agriculture with moderate and high level was going to be submerged in to the water of 5 large dams (Table 2). The similar results were achieved also during the study of Yildirimer (2013). Yildirimer (2013) indicated that according to the forest management plans, the agricultural land of 159 ha was going to be submerged into Muratli Dam, the agricultural land of 167 ha into Borçka Dam, the agricultural land of 469 ha into Deriner Dam, the agricultural land of 60 ha into Artvin Dam and the agricultural land of 1104 ha into Yusufeli Dam (a total agricultural land of 1959 ha). During the study conducted by Toker (2010), the sizes of the agricultural lands submerged into the reservoir areas of Muratli, Borçka and Deriner Dams were determined. Accordingly, it was indicated that the agricultural land of 824 ha in total $w$ as submerged into the $w$ ater of these three dams. Likewise, considering the expropriation data, it was calculated that 3800 parcels were expropriated due to Artvin Dam and that the agricultural land of 83 ha was submerged into the water of Artvin Dam. As the expropriation process of Yusufeli Dam continues, the data could not be obtained related to the expropr iated agricultural lands due to this dam.

In conclusion, when the pasture, forest and reservoir areas were excluded from the land of 126058.15 ha that was particularly determined as suitable for agriculture with moderate and high level, it was determined that only an area of 30736.09 ha could be used for agricultural purpose. The low rate of highly suitable agricultural land found in this study can be associated with the factors of the severe slope, the high erosion degrees and the shallow soil depth of the research. Similarly, a study conducted in Ispir, Erzurum (Turkey) to assess the suitability of agricultural lands has also resulted in low rate $(0.9 \%)$ of highly suitable agricultural lands (Demir et al., 2011) and the authors related these outcomes to the high average slope rate in the region of Ispir, limiting potential areas suitable for agriculture practices. Moreover, in a research completed in Darjeeling district of India, it was determined that only $5.31 \%$ of the study area was highly suitable for agricultural production, mostly due to the facts that the majority of the land use type was forest (with 65\%) besides the high slope degrees of the district (Pramanik, 2016).

\section{CONCLUSION}

In this study aiming to determine the alternative lands suitable for agriculture on the scale of Borçka, Murgul, Central, Ardanuç and Yusufeli districts of Artvin; GIS and AHP method, being one of the multicriteria decision making analysis methods, were utilized. The study was realized by using 9 criteria 
reflecting the topographic characteristics and the soil structure of the area. As a result of the evaluation, it was determined that $9.8 \%$ of the study area is suitable for agricultural production. In addition, considering the forest and pasture areas within the borders of the study area and the areas within the reservoir areas of the dams, it was determined that about $85 \%$ of the lands being suitable for agricultural production coincides with these areas and accordingly that they could not be used for agricultural purpose.

It was determined that there were two main reasons for the fact that the rate of land being suitable for agriculture was such low. The main and the most influential reason is that the majority of the lands determined as being suitable for agriculture in the study area coincides with the current forest and pasture areas. The forest and pasture legislation in force in Turkey does not allow the forest and pasture areas to be used for any other purpose, including agricultural production, in order to protect these areas. Therefore, these areas corresponding to about $85 \%$ of the study area were excluded from the evaluation. The second reason is the problems arising from the geomorphologic characteristics of the study area. Corresponding to the dominant great soil group in the study area, the brown forest soil does not have any inconvenience in terms of plant production other than its slight acidic characteristics. How ever, the problems arising from the geomorphologic situation of the area such as high slope degree had negative impacts on the erosion severity, the rate of bare rock areas, the soil depth and the land use capability classification. All of these inconveniences caused a low rate of land, on the study area, where plant production could be performed.

\section{REFERENCES}

Akbulak, C., 2010, “Analitik Hiyerarşi Süreci ve Coğrafi Bilgi Sistemleri ile Yukarı Kara Menderes Havzası'nın Arazi Kullanımı Uygunluk Analizi", Uluslararası İnsan Bilimleri Dergisi, Vol. 7(2), pp. 557-576.

Akıncı, H., Yavuz Özalp, A., Turgut, B., 2013, “Agricultural Land Use Suitability Analysis Using GIS and AHP Technique", Computer and Electronics in Agriculture, Vol. 97 (2013), pp. 71-82.

Akten, M., Yılmaz, O., Gül, A., 2009, “Alan Kullanım Planlamasında Rekreasyonel Alan Kullanım Ölçütlerinin Belirlenmesi: Isparta Ovası Örneği", Süleyman Demirel Üniversitesi Orman Fakültesi Dergisi, Vol. 2 (2009), pp. 119-133.

Al-Shalabi, M.A., Mansor, S.B., Ahmed, N.B., Shiriff, R., "GIS Based Multicriteria Approaches to Housing Site Suitability Assessment", XXIII FIG Congress, 8-13 October 2006, Germany.

Amiri, F., Shariff, A.R.B.M., 2012, "Application of Geographic Information Systems in Landuse Suitability Evaluation for Beekeeping: A Case Study of Vahregan Watershed (Iran)", African Journal of Agricultural Research, Vol. 7(1), pp. 89-97.

Atalay, İ., 2006, Toprak Oluşumu, Simflandırl ması ve Coğrafyası, Meta Basım Matbaacılık, İzmir.

Bandyopadhyay, S., Jaiswal, R.K., Hegde, V.S., Jayaraman, V., 2009, “Assessment of Land Suitability Potentials for Agriculture Using A Remote Sensing and GIS Based Approach", International Journal of Remote Sensing, Vol. 30(4), pp. 879-895.

Bozdağ, A., Yavuz, F., Günay, A.S., 2016, “AHP and GIS Based Land Suitability Analysis for Cihanbeyli (Turkey) County", Environmental Earth Sciences, (2016) 75:813, DOI 10.1007/s12665-016-5558-9.

Demir, M., Demircioglu Yıldız, N., Bulut, Y., Yılmaz, S., Özer, S., 2011, “Alan Kullanım Planlamasında Potansiyel Tarım Alanlarının Ölçütlerinin Coğrafi Bilgi Sistemleri (CBS) Yöntemi ile Belirlenmesi (Ispir Örneği)", Iğdır Üniversitesi Fen Bilimleri Enstitüsü Dergisi, Vol. 1 (3), pp. 7786.

Duc, T.T., 2006, "Using GIS and AHP Technique for Land-use Suitability Analysis", International Symposium on Geoinformatics for Spatial Infrastructure Development in Earth and Allied Sciences (GIS-IDEAS 2006), 9-11 November 2006, Ho Chi Minh City, Vietnam.

FAO, 1976, A Framework for Land Evaluation, Soils Bulletin 32, FAO and Agriculture Organization of the United Nations, Rome. 
Feizizadeh, B., Blaschke, T., 2013, “Land Suitability Analysis for Tabriz County, Iran: A Multi-Criteria Evaluation Approach Using GIS", Journal of Environmental Planning and Management, Vol. 56(1), pp. 1-23.

Fu, Z., Li, Z., Zai, C., Shi, Z., Xu, Q., Wang, X., 2011, “Soil Thickness Effect on Hydrological and Erosion Characteristics Under Sloping Lands: A Hydropedological Perspective", Geoderma, Vol. 167, pp. 41-53.

Gessler, P.E., Chadwick, O.A., Chamran, F., Althouse, L., Holmes, K., 2000, “Modeling Soil-landscape and Ecosystem Properties Using Terrain Attributes", Soil Science Society of America Journal, Vol. 64, pp. 2046-2056.

Kavas, E., 2009, “Analitik Hiyerarşik Süreç Yöntemiyle İzmir İlinde Heyelan Duyarlılığının Coğrafi Bilgi Sistemleri Tabanlı İncelenmesi", TMMOB Coğrafi Bilgi Sistemleri Kongresi (CBS2009), 02-06 Kasım 2009, İzmir.

Koulouri, M., Giourga, C., 2007, “Land Abandonment and Slope Gradient as Key Factors of Soil Erosion in Mediterranean Terraced Lands", Catena, Vol. 69(3), pp. 274-281.

Lobo, D., Lozano, Z., Delgado, F., 2005, "Water Erosion Risk Assessment and Impact on Productivity of A Venezuelan Soil", Catena, Vol. 64(2-3), pp. 297-306.

Malczewski, J., 1999, GIS and Multicriteria Decision Analysis, John Wiley and Sons, New York.

Mishra, A.K., Deep, S., Choudhary, A., 2015, “Identification Of Suitable Sites for Organic Farming Using AHP \& GIS", The Egyptian Journal of Remote Sensing and Space Sciences, Vol. 18, pp. 181-193.

Mokarram, M., Aminzadeh, F., 2010, “GIS-based Multicriteria Land Suitability Evaluation Using Ordered Weight Averaging with Fuzzy Quantifier: A Case Study in Shavur Plain, Iran", The International Archives of the Photogrammetry, Remote Sensing and Spatial Information Sciences, Vol. 38(II), pp. 508-512.

Mustafa, A.A., Singh, M., Sahoo, R.N., Ahmed, N., Khanna, M., Sarangi, A., Mishra, A.K., 2011, “Land Suitability Analysis For Different Crops: A Multi Criteria Decision Making Approach Using Remote Sensing and GIS", Researcher, Vol. 3(12), pp. 61-84.

Öztürk, D., Batuk, F., 2007, “Çok Sayıda Kriter ile Karar Vermede Kriter Ağırlıkları”, Yıldız Teknik Üniversitesi Sigma Mühendislik ve Fen Bilimleri Dergisi, Vol. 25(1), pp. 86-98.

Öztürk, D., Batuk, F., 2010, “Konumsal Karar Problemlerinde Analitik Hiyerarşi Yönteminin Kullanılması", Yıldız Teknik Üniversitesi Sigma Mühendislik ve Fen Bilimleri Dergisi, Vol. 28, pp. 124-137.

Parakash, T.N., 2003, Land Suitability Analysis for Agricultural Crops: A Fuzzy Multicriteria Decision Making Approach, Msc Thesis, The International Institute for Geo-information Science and Earth Observation (ITC), Enschede, The Netherlands.

Perveen, M.F., Nagasawa, R., Uddin, M.I., Delowar, H.K.M., 2007, “Crop-Land Suitability Analysis Using A Multicriteria Evaluation \& GIS Approach", 5th International Symposium on Digital Earth (ISDE5), 5-9 June 2007, University of California, Berkeley, USA.

Pramanik, M.K., 2016, “Site Suitability Analysis for Agricultural Land Use of Darjeeling District Using AHP and GIS techniques", Modeling Earth Systems and Environment, Vol. 2(2), pp. 1-22, DOI 10.1007/s40808-016-0116-8.

Romeijn, H., Faggian, R., Diogo, V., Sposito, V., 2016, “Evaluation of Deterministic and Complex Analytical Hierarchy Process Methods for Agricultural Land Suitability Analysis in a Changing Climate", ISPRS International Journal of Geo-Information, Vol. 5(6), 99; doi:10.3390/ijgi5060099.

Saaty, T.L., 1980, The Analytic Hierarchy Process: Planning, Priority Setting, Resource Allocation, McGrawHill International, New York, NY, U.S.A.

Saaty, T.L., 1990, "An Exposition of the AHP in Reply to The Paper 'remarks on The Analytic Hierarchy Process", Management Science, Vol. 36, pp. 259-268.

Saaty, T.L., 2004, “Mathematical Methods of Operations Research", Dover Publications, Mineola, 415447. 
Toker, E., 2010, Borçka ve Deriner Barajlarmın Çoruh Havzasında Neden Olduğu Arazi Kullanım Değ işiminin ve Arazi Tahribatmm Irdelenmesi, Msc Thesis, Artvin Çoruh Üniversitesi Fen Bilimleri Enstitüsü, Orman Mühendisliği Anabilim Dalı, Artvin.

Tombuş, F.E., 2005, Uzaktan Algılama ve Coğrafi Bilgi Sistemleri Kullanılarak Erozyon Risk Belirlemesine Yeni Bir Yaklaşım, Çorum İli Örneği, Msc Thesis, Anadolu Üniversitesi, Fen Bilimleri Enstitüsü, Uzaktan Algılama ve Coğrafi Bilgi Sistemleri Anabilim Dalı, Eskişehir.

Yavuz Özalp, A., Akıncı, H., Temuçin Kılıçer, S., 2013, “Artvin Ili Arazisinin Topografik ve Bazı Fiziksel Özelliklerinin Tespiti ve Bu Özelliklerin Arazi Örtüsü Ile Ilişkisinin Incelenmesi”, Artvin Çoruh Üniversitesi Orman Fakültesi Dergisi, Vol. 14, pp. 292-309.

Yalew, S.G., van Griensven, A., Mul, M.L., van der Zaag, P., 2016, “Land Suitability Analysis for Agriculture in The Abbay Basin Using Remote Sensing, GIS and AHP Techniques", Modeling Earth Systems and Environment, Vol. 2(2) 2:101, DOI 10.1007/s40808-016-0167-x.

Yıldırımer, S., 2013, Çoruh Nehri Üzerinde Tamamlanan, Inş̧ası Devam Eden ve Planlanan Büyük Barajlarn Neden Olduğu ve Olacağı Arazi Kullanım Değişimlerinin Belirlenmesi, Msc Thesis, Artvin Çoruh Üniversitesi Fen Bilimleri Enstitüsü, Orman Mühendisliği Anabilim Dalı, Artvin.

Zengin, M., Yılmaz, S., 2008, “Ardahan Kura Nehri Ve Yakın Çevresi Alan Kullanımlarının Belirlenmesi ve Optimal Alan Kullanım Önerileri”, Atatürk Üniversitesi Ziraat Fakültesi Dergisi, Vol. 39(1), pp. 43-54. 